\title{
Synthesis, Structure and Magnetic Properties of Layered Perovskite $\mathrm{Sm}_{1.5} \mathrm{SrBa}_{0.5} \mathrm{Mn}_{2} \mathrm{O}_{7}$
}

\author{
M. Oubla • M. Lamire - H. Lassri • S. Benmokhtar • \\ E.K. Hlil
}

Received: 28 November 2013 / Accepted: 16 January 2014 / Published online: 1 February 2014

(C) The Author(s) 2014. This article is published with open access at Springerlink.com

\begin{abstract}
The layered perovskite oxide $\mathrm{Sm}_{1.5} \mathrm{SrBa}_{0.5}$ $\mathrm{Mn}_{2} \mathrm{O}_{7}$ was synthesized by the conventional method of coprecipitation. Its structure has been solved by powder Xray diffraction. The diffraction patterns are consistent with the $14 / \mathrm{mmm}$ symmetry, with tetragonal lattice parameters $a=3.8398(7) \AA$ and $c=20.3814(5) \AA$. The structure of $\mathrm{Sm}_{1.5} \mathrm{SrBa}_{0.5} \mathrm{Mn}_{2} \mathrm{O}_{7}$ is similar to $\mathrm{Sr}_{3} \mathrm{Ti}_{2} \mathrm{O}_{7}$. Magnetic measurements were also performed in the temperature range 2-360 K. They showed a strong presence of antiferromagnetic interactions below Neel temperature $T_{\mathrm{N}}=25 \mathrm{~K}$. The variation of the magnetization with the magnetic field in a temperature of $5 \mathrm{~K}$ was also analyzed. No saturation was observed up to the high applied magnetic field of $10 \mathrm{~T}$.
\end{abstract}

Keywords Rietveld refinement - Magnetic measurements . Layered perovskite $\cdot \mathrm{X}$-Ray $\cdot$ Manganites

M. Oubla $(\varangle) \cdot$ M. Lamire

Laboratoire de Physico-Chimie des Matériaux Inorganiques,

Faculté des Sciences Aïn-Chock, Université Hassan II,

B.P. 5366 Mâarif, Casablanca, Morocco

e-mail: mh.oubla@gmail.com

H. Lassri

Laboratoire de Physique des Matériaux, Micro-électronique, Automatique et Thermique, Faculté des Sciences Aïn-Chock, Université Hassan II, B.P. 5366 Mâarif, Casablanca, Morocco

\section{S. Benmokhtar}

Laboratory of chemistry and Physics of Materials,

Department of chemistry, Faculty of Sciences,

Ben Msik, Casablanca, Morocco

E.K. Hlil

Institut Néel, CNRS et Université Joseph Fourier, BP 166, 38042 Grenoble cedex 9, France

\section{Introduction}

Recently, the bilayered manganites $\mathrm{Ln}_{2-2 x} \mathrm{Sr}_{1+2 x} \mathrm{Mn}_{2} \mathrm{O}_{7}$ of the Ruddlesden-Popper $\left(\mathrm{ABO}_{3}\right) n$ AO $(n=2)[1,2]$ have attracted much scientific and technologic attention [3-9] owing to their interesting electrical and magnetic properties, in particular the colossal magnetoresistance phenomena (CMR) [10-12] which made these materials potentially useful in several applications from the automotive industry to the magnetic recording.

Numerous systematic studies were dedicated to investigate the structural, electronic and magnetic mechanisms in order to obtain a key tuning of observed magnetoresistance. However, we still believe that the origin of these transitions is related to the double-exchange interactions [13] which implies a ferromagnetic pairing between $\mathrm{Mn}^{3+}\left(\mathrm{t}_{2 \mathrm{~g}}^{3} \mathrm{e}_{\mathrm{g}}^{1}\right)$ and $\mathrm{Mn}^{4+}\left(\mathrm{t}_{2 \mathrm{~g}}^{3} \mathrm{e}_{\mathrm{g}}^{0}\right)$ ions and the Jahn-Teller effect [14]. One of the main obstacles preventing the use of these materials in magnetic industry is the requirement of a very strong magnetic field. Several experimental efforts were devoted to search for new materials with a high magnetoresistance in relatively weak fields $[15,16]$.

Some previous works were about the manganites family of samarium-based double perovskite type [17, 18]. The study of the $\mathrm{Sm}_{1.4} \mathrm{Sr}_{1.6} \mathrm{Mn}_{2} \mathrm{O}_{7}$ showed that this compound presents simultaneously a metal-insulator (M-I) and a rough antiferromagnetic transition at a temperature close to $118 \mathrm{~K}$ [17]. Phases of the $\mathrm{Sm}_{2-2 x} \mathrm{Sr}_{1+2 x} \mathrm{Mn}_{2} \mathrm{O}_{7}$ system (with $x=0.2,0.4,0.5$ ) were also investigated; these studies revealed that the Curie temperature $\left(T_{\mathrm{C}}\right)$ decreases when increasing $x$, and the phase with $x=0.2$ presents a metalinsulator transition (M-I) near $T_{\mathrm{C}}$, and a maximal value of magnetoresistance (MR) of $89.88 \%$ at $105 \mathrm{~K}$ under an external field of $5 \mathrm{~T}$ [18]. Also, the substitution of $\mathrm{Sr}^{2+}$ with $\mathrm{Ba}^{2+}$ in $\mathrm{La}_{1.4}\left(\mathrm{Sr}_{1-x} \mathrm{Ba}_{x}\right)_{1.6} \mathrm{Mn}_{2} \mathrm{O}_{7}$ with $(0.0 \leq x \leq 0.6)$ 
was found to lower the $T_{\mathrm{C}}$ from 161 to $94 \mathrm{~K}$, and to increase the values of magnetic entropy when increasing $x$ [19].

In continuation of our previous work, we will present structural and magnetic studies of a new phase with general formula $\mathrm{Sm}_{1.5} \mathrm{SrBa}_{0.5} \mathrm{Mn}_{2} \mathrm{O}_{7}$. The sample was prepared by the co-precipitation method and characterized by X-ray diffraction (XRD). The magnetic measurements versus temperature and under applied magnetic field will be presented and discussed.

\section{Experimental}

\subsection{Synthesis}

The co-precipitation method was employed to synthesize the $\mathrm{Sm}_{1.5} \mathrm{SrBa}_{0.5} \mathrm{Mn}_{2} \mathrm{O}_{7}$ polycrystalline sample. The starting materials were high-purity powders of $\mathrm{Sm}_{2} \mathrm{O}_{3}$, nitrates of $\mathrm{Sr}\left(\mathrm{NO}_{3}\right)_{2}, \mathrm{Ba}\left(\mathrm{NO}_{3}\right)_{2}$, and $\mathrm{Mn}\left(\mathrm{NO}_{3}\right)_{2} \cdot 4 \mathrm{H}_{2} \mathrm{O}$. First, the high purity powder of $\mathrm{Sm}_{2} \mathrm{O}_{3}$ was dissolved in diluted nitric acid, then $\mathrm{Sr}\left(\mathrm{NO}_{3}\right)_{2}, \mathrm{Ba}\left(\mathrm{NO}_{3}\right)_{2}$, and $\mathrm{Mn}\left(\mathrm{NO}_{3}\right)_{2} \cdot 4 \mathrm{H}_{2} \mathrm{O}$ were added. The solution of mixtures was preheated at $60^{\circ} \mathrm{C}$ to evaporate water, leading to a gel. The resulting powder from heating was then ground and calcined in air at $700{ }^{\circ} \mathrm{C}$ for $24 \mathrm{~h}$. Subsequently, the powder was ground, pressed and sintered in many steps from $900{ }^{\circ} \mathrm{C}$ up to $1400{ }^{\circ} \mathrm{C}$ for $24 \mathrm{~h}$, with intermediate grindings between each step.

\subsection{Instrumental Analysis}

The phase purity and homogeneity were determined from the powder diffraction pattern recorded at room temperature in the range of $2 \theta=10-119^{\circ}$ with a step of 0.02 . The crystalline structure was obtained from Rietveld refinement [20] using the FULLPROF code [21].
The magnetization measurements versus temperature and under applied magnetic field of $0.05 \mathrm{~T}$ were taken in the temperature range of $2-360 \mathrm{~K}$, using a $\mathrm{BS} 2$ magnetometer developed at Néel Institute. Also, magnetizations at $5 \mathrm{~K}$ were measured under several magnetic fields up to $10 \mathrm{~T}$.

\section{Results and Discussions}

\subsection{Structural Characterization}

The structure of the synthesized $\mathrm{Sm}_{1.5} \mathrm{SrBa}_{0.5} \mathrm{Mn}_{2} \mathrm{O}_{7}$ sample was determined by X-ray powder diffraction. The structural refinement of this compound was done by the Rietveld method using Fullprof software. The results show that the sample is single phase and all diffraction peaks are indexed in the quadratic system isotypic to that of $\mathrm{Sr}_{3} \mathrm{Ti}_{2} \mathrm{O}_{7}$ with the I4/mmm as space group.

We noticed that inside the structure of this compound, two separate sites exist that can host $\mathrm{Sm}^{3+}, \mathrm{Ba}^{2+}$, and $\mathrm{Sr}^{2+}$ cations: the first one is the perovskite cage of dodecahedral coordination (site $2 \mathrm{~b}$ ) the other one is of a particular coordination as it is coordinated to nine oxygen atoms: $1+4+4$ (site 4e). Also, we noticed that manganese ions $\mathrm{Mn}^{3+}$ and $\mathrm{Mn}^{4+}$ are located in an octahedral environment site 4e. A refinement of all parameters leads to the following reliability factors: $R_{\mathrm{B}}=7.26 \% R_{\mathrm{F}}=7.50 \% \chi^{2}=1.87$. The refined parameters are: $a=3.8398(7) \AA$, and $c=20.3814(5) \AA$. The structure of $\mathrm{Sm}_{1.5} \mathrm{SrBa}_{0.5} \mathrm{Mn}_{2} \mathrm{O}_{7}$ was generated by ATOMS software [22]. The XRD profile and the structure of $\mathrm{Sm}_{1.5} \mathrm{SrBa}_{0.5} \mathrm{Mn}_{2} \mathrm{O}_{7}$ are respectively presented in Figs. 1 and 2 .

Table 1 summarizes the obtained crystallographic characteristics as well as the atomic positions, while the distances and interatomic angles are gathered in Table 3. To complete the structural study of this compound, we checked that the
Fig. 1 Observed and calculated $\mathrm{X}$-ray powder diffraction patterns for

$\mathrm{Sm}_{1.5} \mathrm{SrBa}_{0.5} \mathrm{Mn}_{2} \mathrm{O}_{7}$ at $300 \mathrm{~K}$ and their difference. Reflection positions are marked for the phase

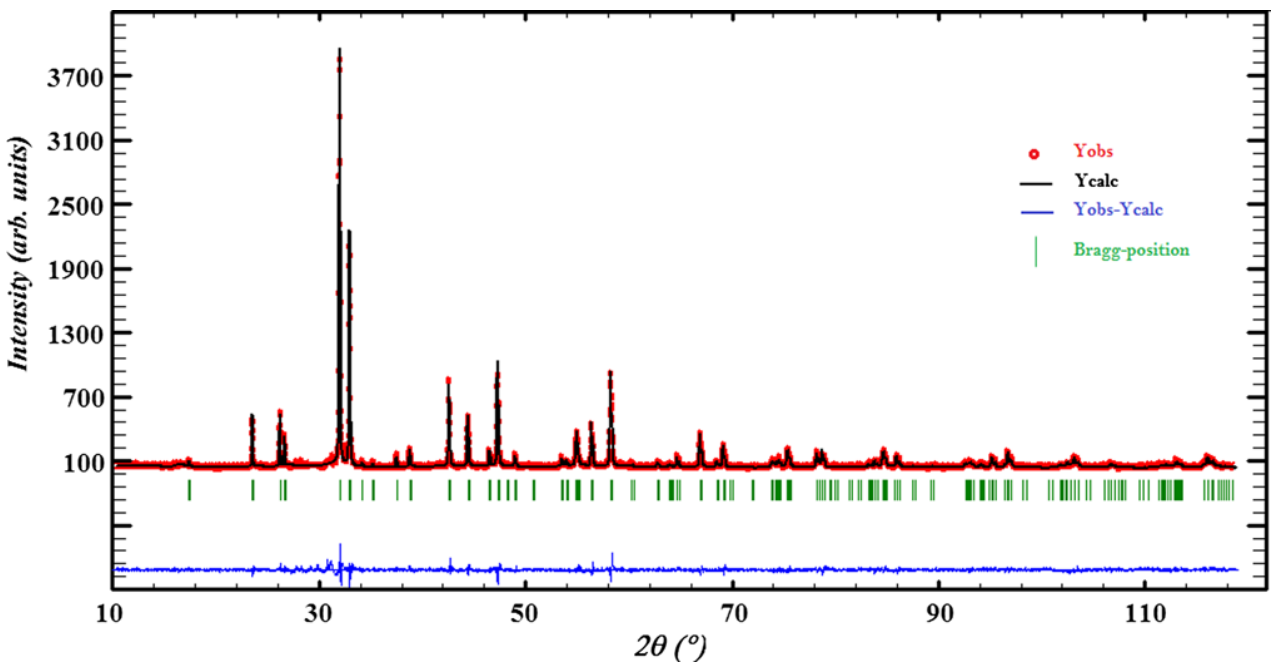


only existence rule on the planes $h k l$ is $h+k+l=2 n$ which implies the presence of a symmetry center in the lattice. The resulting X-ray diffraction lines are presented in Table 4.

A comparison of the unit cell parameters $a, c$ and the ratio $c / a$ as well as the volume of the structure of our compound with those of a similar structure $\mathrm{Sm}_{1.6} \mathrm{Sr}_{1.4} \mathrm{Mn}_{2} \mathrm{O}_{7}$ is summarized in Table 2. It is concluded from this comparison that the parameters $c, c / a$ and the volume of the lattice of

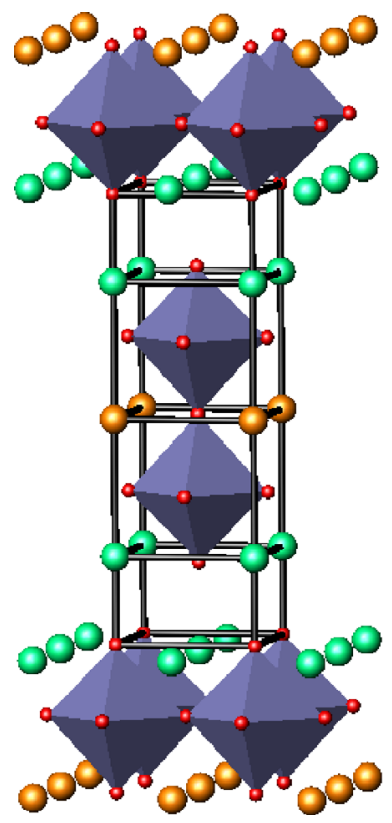

\begin{tabular}{|c|l|}
\hline & $\mathrm{Sm} / \mathrm{Sr} / \mathrm{Ba}$ in 4(e) site \\
\hline$\bigcirc$ & $\mathrm{Sm} / \mathrm{Sr} / \mathrm{Ba}$ in 2(b) site \\
\hline
\end{tabular}

Fig. 2 Unit cell structure of $\mathrm{Sm}_{1.5} \mathrm{SrBa}_{0.5} \mathrm{Mn}_{2} \mathrm{O}_{7}$ our product are slightly larger than those of the similar structure $\mathrm{Sm}_{1.6} \mathrm{Sr}_{1.4} \mathrm{Mn}_{2} \mathrm{O}_{7}$. This is partly due to a relatively large difference between the ionic radii of $\mathrm{Ba}^{2+}(r=1.61 \AA)$ and $\mathrm{Sr}^{2+}(r=1.44 \AA)$, and secondly, due to the $\mathrm{t}_{2 \mathrm{~g}}^{3} \mathrm{~d}_{\mathrm{z} 2}^{1}$ configuration of the $\mathrm{Mn}^{3+}$ ion leading to the Jahn-Teller effect (elongation along $z$ ) which is a cooperative effect.

The $\mathrm{Mn}-\mathrm{O}(i) \quad(i=1,2,3)$ distances range between 1.9216(5) and 2.0178(16) $\AA$, and the $\mathrm{O}-\mathrm{Mn}-\mathrm{O}$ angles are between $89.90(2)^{\circ}$ and $180.0(10)^{\circ}$. We can conclude that manganese in this structure is surrounded by six oxygen atoms, forming a distorted octahedron.

\subsection{Magnetic Characterization}

The magnetization was measured in a large temperature range between 2 and $300 \mathrm{~K}$ using a BS2 magnetometer at Néel institute. The related measurement is presented in Fig. 3. One can notice that the sample cooling under a weak magnetic field of $0.05 \mathrm{~T}$ provokes an increase of the magnetic moment and reaches a maximum at Néel temperature $T_{\mathrm{N}}=25 \mathrm{~K}$, and then decreases to $T=2 \mathrm{~K}$. This result suggests the presence of a strong antiferromagnetic interactions below Néel temperature $T_{\mathrm{N}}=25 \mathrm{~K}$.

The variation of the inverse molar magnetic susceptibility $1 / \chi_{M}$ versus temperature is reported in Fig. 4 . The effective magnetic moment $\left(\mu_{\text {eff }}\right)$ was calculated from the linear zone at high temperatures using the Curie law. The value of $\mu_{\mathrm{eff}}$ is found to be equal to $6.70 \mu_{\mathrm{B}}$, the magnetic moment of manganese $\mu_{\mathrm{Mn}}$ was calculated from the total effective moment and theoretical magnetic moment of samar-

Table 1 Refined structural parameters of $\mathrm{Sm}_{1.5} \mathrm{SrBa}_{0.5} \mathrm{Mn}_{2} \mathrm{O}_{7}$

\begin{tabular}{|c|c|c|c|c|c|c|c|}
\hline & Atom & Position & $x$ & $y$ & $z$ & Biso $\left(\AA^{2}\right)$ & Occupancy \\
\hline \multirow{10}{*}{$\begin{array}{l}\mathrm{Sm}_{1.5} \mathrm{SrBa}_{0.5} \mathrm{Mn}_{2} \mathrm{O}_{7} \\
\mathrm{I} 4 / m m m \\
Z=2 \\
a=b=3.8398(7) \AA \\
c=20.3814(5) \AA \\
R_{B}=7.26 \% \\
R_{F}=7.50 \% \\
\chi^{2}=1.87 \\
V=300.52 \AA^{3}\end{array}$} & Mn & $4 \mathrm{e}$ & 0.0 & 0.0 & $0.0990(2)$ & $0.2410(5)$ & 2.00000 \\
\hline & $\operatorname{Sr}(1)$ & $2 b$ & 0.0 & 0.0 & 0.5 & $0.590(10)$ & $0.4810(14)$ \\
\hline & Sm (1) & $2 b$ & 0.0 & 0.0 & 0.5 & $0.590(10)$ & $0.3520(14)$ \\
\hline & $\mathrm{Ba}(1)$ & $2 b$ & 0.0 & 0.0 & 0.5 & $0.590(10)$ & 0.16666 \\
\hline & $\operatorname{Sr}(2)$ & $4 \mathrm{e}$ & 0.0 & 0.0 & 0.31611 & $0.580(5)$ & $0.5190(14)$ \\
\hline & Sm (2) & $4 \mathrm{e}$ & 0.0 & 0.0 & 0.31611 & $0.580(5)$ & $1.1480(14)$ \\
\hline & $\mathrm{Ba}(2)$ & $4 \mathrm{e}$ & 0.0 & 0.0 & 0.31611 & $0.580(5)$ & 0.33333 \\
\hline & $\mathrm{O}(1)$ & $2 a$ & 0.0 & 0.0 & 0.0 & $1.34(19)$ & 1 \\
\hline & $\mathrm{O}(2)$ & $8 \mathrm{~g}$ & 0.0 & 0.5 & $0.1029(6)$ & $1.34(19)$ & 4 \\
\hline & $\mathrm{O}(3)$ & $4 \mathrm{e}$ & 0.0 & 0.0 & $0.2008(8)$ & $1.34(19)$ & 2 \\
\hline
\end{tabular}

Table 2 Volume and unit cell parameters $a, c$ and the ratio $c / a$ of the $\mathrm{Sm}_{1.5} \mathrm{SrBa}_{0.5} \mathrm{Mn}_{2} \mathrm{O}_{7}$ structure and those of $\mathrm{Sm}_{1.6} \mathrm{Sr}_{1.4} \mathrm{Mn}_{2} \mathrm{O}_{7}($ which are used as a reference)

\begin{tabular}{llllll}
\hline Structure & $a(\AA)$ & $c(\AA)$ & $c / a$ & $V\left(\AA^{3}\right)$ & References \\
\hline $\mathrm{Sm}_{1.6} \mathrm{Sr}_{1.4} \mathrm{Mn}_{2} \mathrm{O}_{7}$ & 3.8433 & 19.9946 & 5.20 & 295.33 & {$[18]$} \\
$\mathrm{Sm}_{1.5} \mathrm{SrBa}_{0.5} \mathrm{Mn}_{2} \mathrm{O}_{7}$ & 3.8398 & 20.3814 & 5.31 & 300.51 & Our work \\
\hline
\end{tabular}


Table 3 Bond lengths and angles of $\mathrm{Sm}_{1.5} \mathrm{SrBa}_{0.5} \mathrm{Mn}_{2} \mathrm{O}_{7}$

\begin{tabular}{lllr}
\hline Atoms & Bond lengths $(\AA)$ & Atoms & Bond angles $\left(^{\circ}\right)$ \\
\hline $\mathrm{Mn}-\mathrm{O}(1)$ & $1 \times 2.0178(16)$ & $\mathrm{O}(1)-\mathrm{Mn}-\mathrm{O}(2)$ & $92.4(4)$ \\
$\mathrm{Mn}-\mathrm{O}(2)$ & $4 \times 1.9216(5)$ & $\mathrm{O}(1)-\mathrm{Mn}-\mathrm{O}(3)$ & $180.0(10)$ \\
$\mathrm{Mn}-\mathrm{O}(3)$ & $1 \times 2.0748(23)$ & $\mathrm{O}(2)-\mathrm{Mn}-\mathrm{O}(2)$ & $175.26(2)$ \\
$\mathrm{Sm} / \mathrm{Sr} / \mathrm{Ba}(1)-\mathrm{O}(1)$ & $4 \times 2.7152(14)$ & $\mathrm{O}(2)-\mathrm{Mn}-\mathrm{O}(2)$ & $89.90(2)$ \\
$\mathrm{Sm} / \mathrm{Sr} / \mathrm{Ba}(1)-\mathrm{O}(2)$ & $8 \times 2.8430(9)$ & $\mathrm{O}(2)-\mathrm{Mn}-\mathrm{O}(3)$ & $87.6(7)$ \\
$\mathrm{Sm} / \mathrm{Sr} / \mathrm{Ba}(2)-\mathrm{O}(2)$ & $4 \times 2.5310(8)$ & $\mathrm{O}(1)-\mathrm{Sm} / \mathrm{Sr} / \mathrm{Ba}(1)-\mathrm{O}(1)$ & $90.00(2)$ \\
$\mathrm{Sm} / \mathrm{Sr} / \mathrm{Ba}(2)-\mathrm{O}(3)$ & $4 \times 2.7370(2)$ & $\mathrm{O}(2)-\mathrm{Sm} / \mathrm{Sr} / \mathrm{Ba}(1)-\mathrm{O}(2)$ & $179.9(6)$ \\
$\mathrm{Sm} / \mathrm{Sr} / \mathrm{Ba}(2)-\mathrm{O}(3)$ & $1 \times 2.3518(16)$ & $\mathrm{O}(3)-\mathrm{Sm} / \mathrm{Sr} / \mathrm{Ba}(2)-\mathrm{O}(3)$ & $89.08(6)$ \\
\hline
\end{tabular}

Table 4 Powder X-ray diffraction data of $\mathrm{Sm}_{1.5} \mathrm{SrBa}_{0.5} \mathrm{Mn}_{2} \mathrm{O}_{7}$

\begin{tabular}{|c|c|c|c|c|c|c|}
\hline$h$ & $k$ & $l$ & $d_{\text {obs }}(\AA)$ & $d_{\text {cal }}(\AA)$ & $I_{\mathrm{obs}}$ & $I_{\mathrm{cal}}$ \\
\hline 1 & 0 & 1 & 3.768 & 3.773 & 10 & 12 \\
\hline 0 & 0 & 6 & 3.393 & 3.398 & 11 & 10 \\
\hline 1 & 0 & 3 & 3.338 & 3.343 & 6 & 5 \\
\hline 1 & 0 & 5 & 2.793 & 2.795 & 100 & 100 \\
\hline 1 & 1 & 0 & 2.713 & 2.715 & 59 & 62 \\
\hline 1 & 1 & 4 & 2.395 & 2.396 & 3 & 3 \\
\hline 1 & 0 & 7 & 2.318 & 2.320 & 4 & 4 \\
\hline 1 & 1 & 6 & 2.120 & 2.121 & 24 & 24 \\
\hline 0 & 0 & 10 & 2.037 & 2.038 & 15 & 13 \\
\hline 1 & 0 & 9 & 1.950 & 1.950 & 3 & 3 \\
\hline 2 & 0 & 0 & 1.919 & 1.919 & 32 & 34 \\
\hline 1 & 1 & 8 & 1.857 & 1.857 & 3 & 3 \\
\hline 2 & 0 & 0 & 1.919 & 1.919 & 32 & 34 \\
\hline 2 & 1 & 1 & 1.711 & 1.711 & 2 & 3 \\
\hline 1 & 0 & 11 & 1.668 & 1.668 & 7 & 7 \\
\hline 1 & 1 & 10 & 1.629 & 1.630 & 13 & 13 \\
\hline 2 & 1 & 5 & 1.582 & 1.582 & 34 & 35 \\
\hline 1 & 1 & 12 & 1.439 & 1.430 & 4 & 4 \\
\hline 2 & 0 & 10 & 1.3971 & 1.397 & 12 & 12 \\
\hline 2 & 2 & 0 & 1.357 & 1.357 & 9 & 9 \\
\hline 2 & 1 & 11 & 1.259 & 1.259 & 5 & 5 \\
\hline 3 & 1 & 0 & 1.214 & 1.214 & 8 & 8 \\
\hline 3 & 1 & 6 & 1.143 & 1.143 & 5 & 5 \\
\hline 3 & 2 & 5 & 1.030 & 1.030 & 9 & 9 \\
\hline 4 & 1 & 5 & 0.907 & 0.908 & 8 & 8 \\
\hline
\end{tabular}

ium ion $\mathrm{Sm}^{3+}$ using the relation proposed by Subramanian et al. [23]: $\mu_{\text {eff }}^{2}=n_{1} \mu^{2}\left(\mathrm{Sm}^{3+}\right)+n_{2} \mu^{2}(\mathrm{Mn})$ where $n_{1}=1.5$ and $n_{2}=2.0$ are the numbers of samarium ion $\mathrm{Sm}^{3+}$ and manganese ion in mixed $\mathrm{Mn}^{3+}$ and $\mathrm{Mn}^{4+}$, respectively. The $\mu\left(\mathrm{Sm}^{3+}\right)$ is the theoretical magnetic moment $\left(0.84 \mu_{\mathrm{B}}\right)$ of samarium ion $\mathrm{Sm}^{3+}$ and $\mu(\mathrm{Mn})$ is the magnetic moment of manganese. We obtained a value of $4.63 \mu_{\mathrm{B}}$ for $\mu(\mathrm{Mn})$. Using the latter value of $\mu(\mathrm{Mn})$ and the theoretical values of moments for both $\mathrm{Mn}^{3+}$ and $\mathrm{Mn}^{4+}$, which are $4.9 \mu_{\mathrm{B}}$ and $3.9 \mu_{\mathrm{B}}$, respectively, we found $78 \%$ and $22 \%$ of $\mathrm{Mn}^{3+}$ and $\mathrm{Mn}^{4+}$ ions, respectively. Such percentages are close to the theoretical percentages $75 \%$ and $25 \%$ of $\mathrm{Mn}^{3+}$ and $\mathrm{Mn}^{4+}$, respectively.

The Curie-Weiss temperature $T_{\mathrm{C}}=110 \mathrm{~K}$ was determined by applying a linear extrapolation to the curve presenting the inverse of molar magnetic susceptibility 


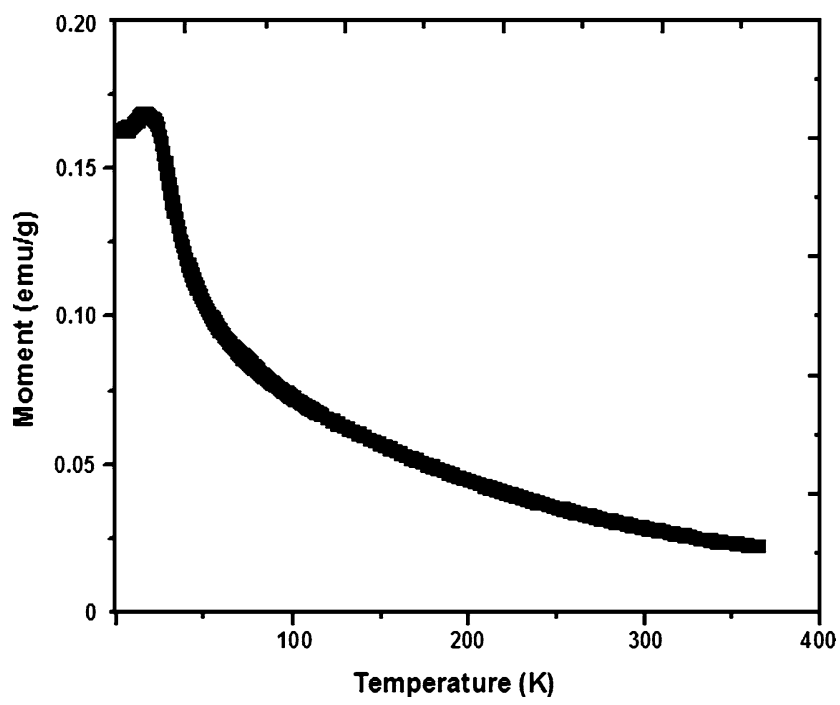

Fig. 3 Temperature dependence of the magnetization in a magnetic field of $0.05 \mathrm{~T}$ for $\mathrm{Sm}_{1.5} \mathrm{SrBa}_{0.5} \mathrm{Mn}_{2} \mathrm{O}_{7}$

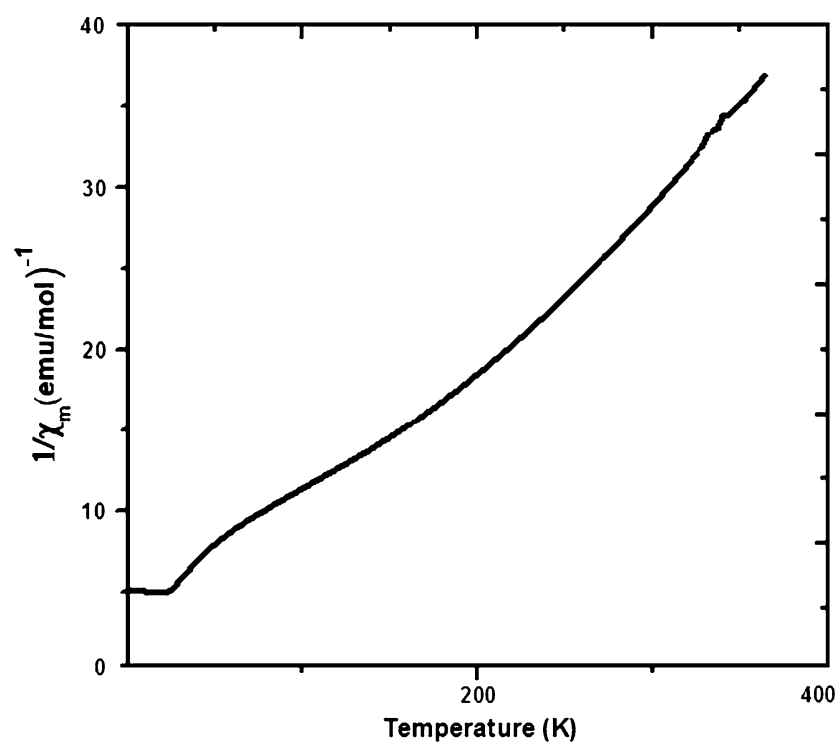

Fig. 4 Inverse molar susceptibility $\left(1 / \chi_{M}\right)$ vs. temperature for $\mathrm{Sm}_{1.5} \mathrm{SrBa}_{0.5} \mathrm{Mn}_{2} \mathrm{O}_{7}$ obtained from magnetization measurements in a field of $0.05 \mathrm{~T}$

Table 5 Calculated and theoretical magnetic characteristics of the studied compound $\mathrm{Sm}_{1.5} \mathrm{SrBa}_{0.5} \mathrm{Mn}_{2} \mathrm{O}_{7}$ in a magnetic field of $0.05 \mathrm{~T}$

\begin{tabular}{|c|c|c|c|c|c|}
\hline$T_{\mathrm{N}}$ & $C$ (the) & $C$ (calc) $\mu_{\text {eff }}$ (the) & $\mu_{\text {eff }}$ (calc) & $\% \mathrm{Mn}^{3+}$ & $\% \mathrm{Mn}^{4+}$ \\
\hline $25 \mathrm{H}$ & 110 K 5.54 & $6.66 \mu_{\mathrm{B}}$ & $6.70 \mu_{\mathrm{B}}$ & $78 \%$ & $22 \%$ \\
\hline
\end{tabular}

versus of temperature. Table 5 summarizes the calculated and theoretical magnetic characteristics of the studied $\mathrm{Sm}_{1.5} \mathrm{SrBa}_{0.5} \mathrm{Mn}_{2} \mathrm{O}_{7}$ compound.

The dependence of the magnetization as a function of the magnetic field, reported in Fig. 5, revealed the absence

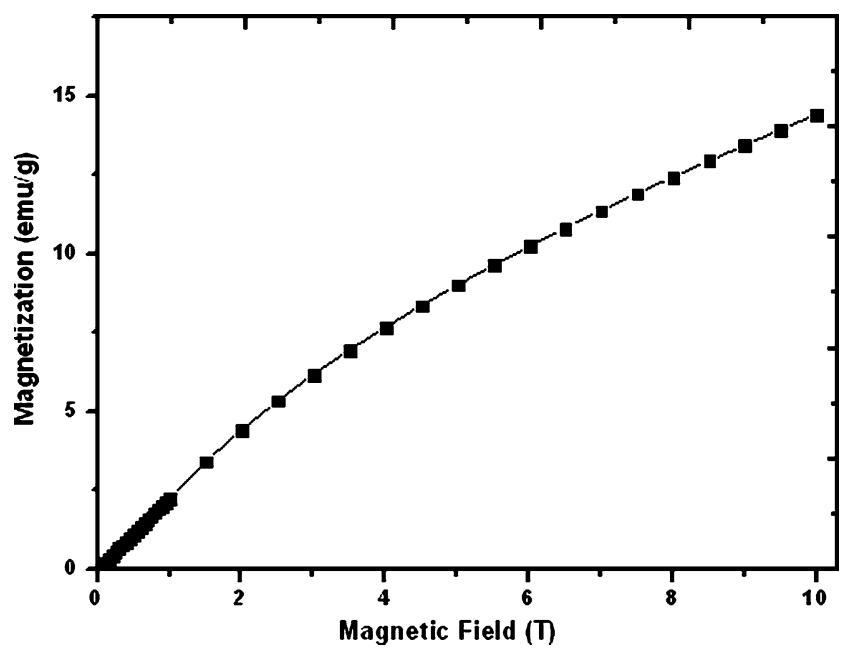

Fig. 5 Magnetization vs. field at $5 \mathrm{~K}$ of $\mathrm{Sm}_{1.5} \mathrm{SrBa}_{0.5} \mathrm{Mn}_{2} \mathrm{O}_{7}$

of saturation even with strong magnetic fields (the maximal magnetic field $\approx 10 \mathrm{~T}$ ). This phenomenon can be explained by the fact that $\mathrm{Mn}^{3+}, \mathrm{Mn}^{4+}$ and $\mathrm{Sm}^{3+}$ ions are the elements carrying magnetic moments. This should lead to a competition of magnetic interactions between these ions at a low temperature. Similar behavior was observed in the $\mathrm{Er}_{2} \mathrm{Mn}_{2} \mathrm{O}_{7}$ [24] compound in which magnetic interaction between erbium ions $\mathrm{Er}^{3+}$ and manganese $\mathrm{Mn}^{4+}$ takes place.

\section{Conclusions}

A new phase with the composition $\mathrm{Sm}_{1.5} \mathrm{SrBa}_{0.5} \mathrm{Mn}_{2} \mathrm{O}_{7}$ has been synthesized by conventional co-precipitation method. Its structure has been determined by the Rietveld analysis of XRD data. The results point out to the tetragonal lattice with the $I 4 / \mathrm{mmm}$ as space group. The magnetic measurements revealed that the compound shows antiferromagnetic behavior with a Néel temperature of $25 \mathrm{~K}$. No magnetization saturation was observed even when the magnetic field increased up to $10 \mathrm{~T}$. The presence of $\mathrm{Mn}$ in different valence states was confirmed by magnetic susceptibility measurements. Results are in good agreement with structural data.

Open Access This article is distributed under the terms of the Creative Commons Attribution License which permits any use, distribution, and reproduction in any medium, provided the original author(s) and the source are credited.

\section{References}

1. Ruddlesden, S.N., Popper, P.: Acta Crystallogr. 10, 538-539 (1957)

2. Ruddlesden, S.N., Popper, P.: Acta Crystallogr. 11, 54-55 (1958) 
3. Jin, S., Tiefel, T.H., McCormack, M., Fastnacht, R.A., Ramesh, R., Chen, L.H.: Science 264, 413 (1993)

4. Rao, C.N.R., Cheetham, A.K., Mahesh, R.: Chem. Mater. 8, 2421 (1996)

5. Mahendiran, R., Tiwary, S.K., Raychaudhuri, A.K., Ramakrishnan, T.V., Mahesh, R., Rangavittal, N., Rao, C.N.R.: Phys. Rev. B 53, 3348 (1996)

6. Tiwari, A., Rajeev, K.P.: Phys. Rev. B 60, 10591 (1999)

7. Lofland, S.E., Bhagat, S.M., Ghosh, K., Greene, R.L., Karabashev, S.G., Shulayatev, D.A., Arsenov, A.A., Mukovskii, Y.: Phys. Rev. B 56, 13705 (1997)

8. Tiwari, A., Chugh, A., Jin, C., Kumar, D., Narayan, J.: Solid State Commun. 121, 679 (2002)

9. Tiwari, A., Rajeev, K.P.: Solid State Commun. 111, 33 (1999)

10. Rao, C.N.R., Raveau, B. (eds.): Colossal Magnetoresistance, Charge Ordering and Related Properties of Manganese Oxides. World Scientific, Singapore (1998)

11. Haghiri-Gosnet, A.-M., Renard, J.-P.: J. Phys. D, Appl. Phys. 36, R127 (2003)

12. Prellier, W., Lecoeur, Ph., Mercey, B.: J. Phys. Condens. Matter 13, R915 (2001)

13. Zener, C.: Phys. Rev. 82, 403 (1951)
14. Millis, A.J., Littlewood, P.B., Shraiman, B.I.: Phys. Rev. Lett. 74, 5144 (1995)

15. Hwang, H.Y., Cheong, S.-W.: Nature 389, 942 (1997)

16. Sun, J.Z., Gallagher, W., Duncombe, P.R., Krusin-Elbaum, L., Altman, R.A., Gupta, A., Lu, Yu., Gong, G.Q., Xiao, G.: Appl. Phys. Lett. 69, 3266 (1996)

17. Hur, N.H., Chi, E.O., Kwon, Y.U., Yu, J., Kim, J.-T., Park, Y.K., Park, J.C.: Solid State Commun. 112, 61 (1999)

18. Liu, J.W., Chen, G., Li, Z.H., Lü, Z., Zhang, Z.G.: Mater. Chem. Phys. 105, 185-188 (2007)

19. Cherif, K., Zemni, S., Dhahri, J., Oumezzine, M., Saida, M., Vincent, H.: J. Alloys Compd. 432, 30-33 (2007)

20. Reitveld, H.M.: J. Appl. Crystallogr. 2, 65 (1969)

21. Rodriguez-Carvajal, J.: FULLPROF: a program for Rietveld refinement and pattern matching analysis. Collected Abstract of Powder Diffraction Meeting, Toulouse, France, vol. 127 (1990)

22. Dowty: ATOMS. Version 5.1. Shape Software E. Kingsport, Tennessee 37663, USA (2000)

23. Subramanian, M.A., Torardi, C.C., Johnson, D.C., Pannetier, J., Sleight, A.W.: J. Solid State Chem. 72, 24 (1988)

24. Amor, N.B., Bejar, M., Dhahri, E., Valente, M.A., Garden, J.L., Hlil, E.K.: J. Alloys Compd. 563, 28-32 (2013) 